\title{
The Future Psychologists' Motivation to Work in the System of Inclusive Education
}

\author{
Viktor Syniov, Maria Sheremet, Daria Suprun, Svitlana Fedorenko, Myroslav Fedorenko, Alla \\ Dushka, Vitalii Lunov, Olha Tsarkova
}

\begin{abstract}
The article is devoted to the research of the future psychologists' readiness to work with children with psychophysical disorders and exist in the conditions of inclusive education, according to the professional and motivational component.

The average level of formation of the specified component is appropriate for 50,0\%. These investigated persons demonstrate mostly positive, but in some cases an uncertain attitude towards various aspects of the future professional activity; in general, they are focused on self-development. Not all students entering university, are guided by the desire to become a psychologist, just prevailing motivation to obtain higher education. The low level is appropriate for 9,5\%. The mostly negative or uncertain attitude towards various aspects of future professional activity and insufficient level of motivation by choosing a profession, its prestige and competitiveness is discovered.

It's determined, that one of the main tasks of the practical psychologists' professional training should be development of scientific bases of their professionally oriented training to work in the system of inclusive education by eliminating small training courses and by creating integrative trans- and interdisciplinary complexes. Activation of the professional and motivational component should take place by introducing into the curriculum a special course "Fundamentals of Axiology" aimed in the professional formation of the system of principles, norms, canons, ideals that regulate interaction in the inclusive educational environment.
\end{abstract}

Revised Manuscript Received on November 15, 2019

* Correspondence Author

Viktor Syniov, Dr. habil., Professor, Acting Member of the National Academy of Pedagogical Sciences of Ukraine, President of the Association of Special Pedagogues of Ukraine, National Pedagogical Dragomanov University, Ukraine

Maria Sheremet, Dr. habil., Professor, Honorary Academician of the National Academy of Pedagogical Sciences of Ukraine, Dean of the Faculty of Special and Inclusive Education Vice-President of the Association of Special Pedagogues of Ukraine, National Pedagogical Dragomanov University, 9, Pyrogova Str., Kyev, Ukraine,

Daria Suprun, Dr. habil., Professor of the department of Special Psychology and Medicine National Pedagogical Dragomanov University, , Ukraine

Svitlana Fedorenko, Dr. habil., Professor, head of the department of speech therapy and logopsychology, National Pedagogical Dragomanov University, Ukraine

Myroslav Fedorenko, PhD of pedagogy, associate professor of the department of Special Psychology and Medicine National Pedagogical Dragomanov University, Kyev, Ukraine

Alla Dushka, Doctor of psychological sciences, Associate professor, Chief Scientist of the Department of Psychological and Pedagogical Support of Children with Special Needs, Nichola Yarmachenko Institute of Special Pedagogics and Psychology of National Academy of Educational Sciences of Ukraine

Vitalii Lunov *, PhD, Associate Professor, Bogomolets National Medical University, Ukraine, email: lunyov_vitaliy@ukr.net

Olha Tsarkova, Professor (Associate), Psy.D., Bogdan Khmelnitsky Melitopol state pedagogical university, Ukraine.
Keywords: psychologist, student, education, motivation, inclusive education.

\section{INTRODUCTION}

Intensification of inclusive processes in Ukraine actualizes the problems of specialists' training of the psychological profile directly involved in the organization and providing the effective functioning of the inclusive educational environment. At the same time, as practice shows, the readiness of psychologists to work in the inclusive educational environment is insufficient, what caused the need to determine the degree of future psychologists' training (practical and special) to work with children with psychophysical disorders in the conditions of the inclusive education, according to professional and motivational component.

\section{THEORY}

Various scientific researches are devoted to numerous issues of psychologists' professional training (Grygorenko, 2019; Dubovyk, 2017; Maksymenko, 1999; Panok, 2003; Poviyakel, 1998; Rudenko, 2019; Syniov, 2016; Suprun, 2005; Suprun, 2016, 2018, 2019; Fedorenko, 2017; Fedorenko, 2017; Chepelev, 1998, etc.). Particular attention is paid to the psychologist' personal qualities as they are related to the specifics of training in higher educational institutions and are characterized by a prolonged period of formation and motivation, self-actualization and self-realization as indicators of the effectiveness of professional activity. The researches by T. Kanivets (Kanivets, 2015), N. Chepeleva (Chepeleva, 1998) and others are devoted to contemporary problems of motivation to future psychologists' professional self-improvement. It should be noted that requirements for motivation forming of psychologist in special educational institutions are due to the high level of diagnostic complexity and corrective work to support children with special educational needs.

Sufficient results of scientific researches have been accumulated in the countries of the European Union, the USA, Canada, the countries of the post-Soviet space, Ukraine that provide scientific prerequisites for theoretical understanding of the phenomenon of psychologists' training in the field of special education for professional activity in the conditions of inclusive education, including: theoretical and methodological and philosophical aspects of inclusive education are outlined, strategies for supporting inclusive education of children with special educational needs are developed (Andrews, 2000; Brandon, 2011; Charlton, 2011; Deppeler, 2013; Dyson, 1999; Florian, 2013; Forlin, 2013; Kim , 2011; Loreman, 2013;

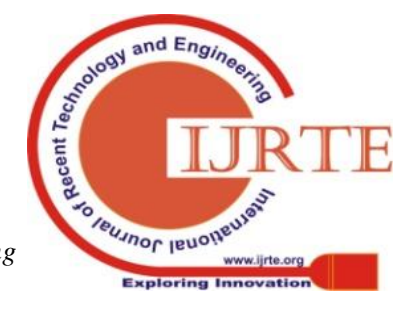


Lupart, 2000; Sharma, 2013; Kolupaeva, 2015; Taranchenko, 2015 , etc.); the ways of professional training, retraining and advanced training of correctional pedagogues and psychologists in the field of special education and in the conditions of inclusive educational space are identified (Demchenko, 2016; Sheremet, 2017; Florian, 2010 etc.).

At the same time, the theoretical analysis of literary sources showed that, despite the diverse scientific spectrum of the phenomena connected with investigating problem, psychologists' professional motivation to work in the field of inclusive education was not the subject of a special holistic scientific research.

The aim of the research was to determine the state of the future psychologists' readiness to work with children with psychophysical disorders in the conditions of inclusive education, according to the professional and motivational component.

\section{METHODS}

The research was attended by 84 students (specialty 053 Psychology, educational program - Practical psychology). So, to achieve the goal, the following research methods were applied: questionnaire, interview, survey, direct and indirect observation of students-psychologists. The following techniques were used: the Rokeach Value Survey (values scales), "The research of the personality professional orientation" (Ye. Rohov), "Motivation to success achievement and failure avoidance" (A. Rean), "Measuring of the Motivation to Achieve Success (MAS) and the Motivation to Avoid Failure. (MAF)" (R. Nemov), Technique of diagnosis personality motivation to success achievement and failure avoidance (T. Ehlers).

Professional motivation occupies a definite place at each specific level of development in the structure of general motivation and is aimed at mastering the achievement skills. The motivation moving to a higher level doesn't reflect the decrease of the integrative qualities of the previous level, but their transformation into more sophisticated. The emotional feelings accompany all processes that reflect the development of a certain motivation.

Determining the levels of the formation of professional motivation, we were guided by the use of range of methodological ideas of psychological theory and practice. Thus, in modern science, the hierarchical levels' distribution is usually carried out in terms of value, temological (the higher is level that meets the goals of individual development) and the structural and functional feature (the motivation changes its structure and functions moving to another level). We determined the motivation peculiarities with such content characteristic as professional significance. The transformation in the motivational sphere, the emergence of changes in it, the formation of qualitatively new formations all this manifests externally in attitude changes to the profession. In this sense, professional significance is one of the integral indicators of motivational sphere of personality. As an indicator, it is closely related to the personality traits and, gaining stability, becomes its characteristic feature (Suprun, 2019). It is known that the process of motivation development is the transition from the management of motivation under the influence of external factors to the conscious management of their own motivation. Acquiring by students the ability to consciously manage and control their own motivation is seen as a significant factor in enhancing professional motivation, which, in fact, provides the motivational qualitative changes.

Therefore, the professional and motivational component of the formation of the components of psychologists' professional readiness of to work in the system of inclusive education is defined as a criterion of motivational readiness for professionalization and the most significant stimulus for acquiring psychological and pedagogical knowledge, skills and abilities. Common criterion indicators of formation of component can be considered: the formation of value orientations; the formation of positive motivational attitude to professional activity; formation of professional motivational direction for success achievement (Suprun, 2018).

On the basis of the defined criteria and indicators and with the help of selected organizational forms and diagnostic methods, four levels of formation of mentioned component have been distinguished: the high (innovative), the sufficient (productive), the middle (reconstructive), and the low (reproductive).

The formation of value orientations necessary for the development of professionally oriented motivation of the studied, was researched according to Rokeach Value Survey (values scales).

\section{RESULTS AND DISCUSSION}

According to the results, the highest subjective significance for the majority, $54,8 \%$ of the total quantity of respondents, received the following values, which were included in the first three basic values: "happy family life", "health", "self-confidence". It's interesting, those who distinguished these values at the first place are introverted persons who are not interested in something that does not affect their own personality. The lower subjective significance, $27,4 \%$ of the total quantity of respondents, received terminal values focused on the macrocommunity, namely: "interesting work", "active life"). This indicates that the respondents are not focused on the organization and management of socially useful activities.

Regarding instrumental values, the most important for psychologists in the field of inclusive education are self-control, education and upbringing, and responsibility. Regarding the unperceived values, the majority $(57,1 \%$ of the respondents) identified nexts: "irreconcilability to the weaknessess of others" and "high demands" indicating the lack of such professional qualities as flexibility, tolerance, projective perception of others.

The formation of a positive motivational attitude and focus on professional activity was determined by the technique "The research of the personality professional orientation" (Ye. Rohov). Through this technique, the respondents had the opportunity to review their attitude to certain aspects of professional activity, perform self-reflection, reflexive possible options for professional development, search for the answer to the questions "Who am I?", "Will I realized as a psychologist?". For the process of psychologists' professional training in the field of inclusive education, this aspect is important, its establishment will contribute to understanding the purpose and motives of the chosen activity.

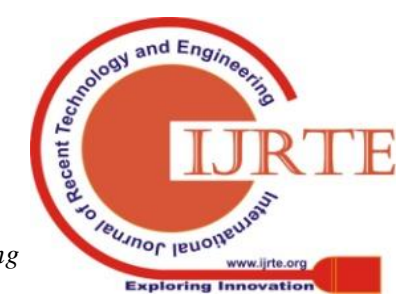


To determine the motivation of choosing a profession, students were offered an author's questionnaire, which consist of the list of motives and make it possible to identify themselves in the field of the chosen specialty. Its application makes it possible to determine the value and motivational priorities, namely: the ability to assess their own position in the chosen activity (activity, interest, attitude to the object of activity). To arise interest, as L. Leontiev claims (Leontiev, 2015), it is necessary to create a motive that will lead to the achievement of the goal. In activities that contribute to increase of interest, the main place is given to the content of a particular subject and, as a result, it is easily remembered by assessing the degree of involvement in the profession, identifying the mechanisms of professional activities affection to the personality, identifying typical psychological deformations of the personality. However, the existence of a huge range of criteria and grounds for typing often complicates such searches. At the same time, some psychologists in the field of inclusive education succeed, finding different fields of activity for themselves. The proposed questionnaire is based on the idea of identifying leading professional orientation (Suprun, 2019).

We process the results from the scale of approval motivation, as in this case, if there is an answer that goes beyond the norm of this factor, then it should be recognized that the respondent sought to distort the results and they are not subject to further interpretation.

According to the results of the survey, 61,9\% of respondents are highly developed "sociability", while "organization" and "professional orientation" are not sufficiently developed at $47,6 \%$. At the satisfactory level is "intelligence" and "approval motivation", what testifies the honesty of responses.

Taking into account the condition of polydiagnostic formation of motivational and professional orientation to success achievement, it was also measured by the following techniques: "Motivation to success achievement and failure avoidance" (A. Rean), "Measuring of the Motivation to Achieve Success (MAS) and the Motivation to Avoid Failure (MAF)" (R. Nemov), Technique of diagnosis personality motivation to success achievement and failure avoidance (T. Ehlers).

The next are results of measuring the level of development of achievement motives (the technique by T. Ehlers). It was revealed that the average (reconstructive) level is appropriate for $51,2 \%$, the low (reproductive) level - for $2,4 \%$, the sufficient (productive) level - for $41,6 \%$, and the high (innovative) level - only for $4,8 \%$.

The results of the mentioned technique should be analyzed together with the results of The following techniques: "Motivation to success achievement and failure avoidance" (A. Rean), "Measuring of the Motivation to Achieve Success (MAS) and the Motivation to Avoid Failure. (MAF)" (R. Nemov) with aim to correct assessment The results of measuring the level of success and achievement and failure avoidance made it possible to establish that the high (innovative) level is appropriate for $2,4 \%$ of the participants of the experiment, the average (reconstructive) level - for $46,4 \%$, the sufficient (productive) - for $36,9 \%$, and the low (reproductive) level - for $14,3 \%$.

The relevant data by the abovementioned techniques allow to determine the level of interest in the field of professional the students. Psychologists often face problems with

activity, the need for mastering and creative providing of innovation in the educational process, the desire to participate in the creation and implementation of a new pedagogical project, providing experimental research, the need to carry out innovative professional activity, beliefs as for needs to prepare the future psychologist for innovative professional activity. In turn, the techniques for Motivation to success achievement and failure avoidance allowed us to determine the levels of motivation to succeed in professional activity.

In order to determine the students' formation of a positive motivational attitude to the professional activity, technique by K. Zamfir was used (modification by A. Rean). It is based on the concept of internal and external motivation. The internal motivation is the most important, when the personality is tending to this professional activity. If the motivation is based on the desire to meet other needs external in content of the activity (motives of social prestige, salaries, etc.). It indicates the existance of external motivation. The external motives are divided into positive (more effective and desirable) and negative ones. In our study were calculated indicators of internal motivation (IM), external positive (EPM) and external negative (ENM) with the following keys:

$$
\begin{gathered}
\mathrm{IM}=\text { score } 6+\text { score } 7 \\
2 \\
\mathrm{EPM}=\text { score } 1+\text { score } 2+\text { score } 5 \\
3 \\
\mathrm{ENM}=\text { score } 3+\text { score } 4 \\
2
\end{gathered}
$$

An indicator of each type of motivation was a number ranging from 1 to 5 (including possible fractions). The best, optimal, motivational complexes include the following combinations' types:

\section{IM $>$ EPM $>$ ENM}

and

\section{$\mathrm{IM}=\mathrm{EPM}>\mathrm{ENM}$}

The worst motivational complex is the type of ENM> EPM> IM. Note that special interest for research was consisted in the level of professional stability (or instability) of the psychologist's personality, that according to A. Rean has a connection with the identified motivational complexes. Thus, in the course of the experimental study we confirmed that there is a negative relative relationship between the optimality of the motivational complex and the level of professional instability of the psychologist's personality. The more the optimal complex, the more the psychologist's activity is motivated by the content of the psychological and pedagogical activity, by the desire to achieve certain positive results in it, so the lower professional instability. Conversely, the more activity is driven by motives to get rid of punishment, the higher the level of professional instability.

Thus, the results of empirical research of professional and motivational component was revealed that the choice of profession and educational and professional activity of future psychologists who will work in the system of inclusive education is polymotivated, that is based on the motives of different groups, and each of them has certain importance for the student at the stage of his professional development.

The high (innovative) level of component formation is appropriate for $2,4 \%$ ( 2 persons).

Published By: 
These students were interested in professional activity, had positive attitude to various aspects of it; had a clear focus on self-knowledge and self-development as a future psychologist, confidence in the importance of their own efforts to achieve this goal. The sufficient (productive) level is appropriate for $38,1 \%$ (32 persons). They showed a positive attitude to future professional activity. The average (reconstructive) level is appropriate for $50,0 \%$ (42 persons). These investigated persons demonstrate mostly positive, but in some cases an uncertain attitude towards various aspects of the future professional activity; in general, they are focused on self-development. Not all students entering university, are guided by the desire to become a psychologist, just prevailing motivation to obtain higher education. The low (reproductive) level is appropriate for $9,5 \%$ ( 8 persons). The mostly negative or uncertain attitude towards various aspects of future professional activity and insufficient level of motivation to choosing a profession, its prestige and competitiveness, uncertain orientation in the significance of management aspect of the psychologist's activity are discovered.

The analysis of the obtained results made it possible to make conclusions about the general average and low level of formation of the professional and motivational component of the students' professional readiness (specialty 053 Psychology, educational program - Practical psychology) to work in the conditions of inclusive education.

\section{Conclusions}

Modern psychologists' professional training for the system of inclusive education is a holistic process consisting of a number of subsystems, each of which performs its function. Diagnosis of psychologists' successful training to work in the system of inclusive education allow not only to receive information for reflection and further analysis, but also must be helpful to determine the directions and prospects for professional growth, formation of adequate professional self-esteem, positive self-concept and psychological comfort of the future specialists (Suprun, 2019).

Based on the results of the research it was concluded that one of the main tasks of the practical psychologists' professional training to work in the system of inclusive education should be the formation of specific professional knowledge, skills and abilities within the framework of special obligatory and elective training courses, special courses aimed at mastering the basics of working with children, with psychophysical disorders.

Activation of the professional and motivational component should take place by introducing into the curriculum a special course "Fundamentals of Axiology" aimed at the professional formation of the system of principles, norms, canons, ideals that regulate interaction in the inclusive educational environment.

The obtained experimental data also confirmed the advisability of psychological and pedagogical motivational trainings in the process of knowledge forming aimed at improving the components of psychologists' professional training to work in the system of inclusive education (Suprun, 2018).

Particular attention should also be paid to the fact that the reform of the educational field under research requires development of scientific bases of their professionally oriented training to work in the system of inclusive education by eliminating small training courses and by creating integrative trans- and interdisciplinary complexes. This would form the basis for mastering the theoretical bases and practical skills of diagnostic, correctional, rehabilitation, advisory and educational work, with the aim for the fundamentalization of professional training in general.

\section{REFERENCES:}

1. Andrews, J. \& Lupart, J. (2000). The inclusive classroom: Educating exceptional children. (2nd Edition). Scarborough, ON: Nelson Canada.

2. Brandon, T. \& Charlton, J. (2011). The lessons learned from developing an inclusive learning and teaching community of practice. International Journal of Inclusive Education, 15(1), 165-178.

3. Chepelieva, N. \& Poviakel, N. (1998). Teoretychne obgruntuvannia modeli osobystosti praktychnoho psykholoha [Theoretical reasoning of the practical psychologist's personality model]. Psykholohiia Psychology, 3, 35-41. [in Ukrainian].

4. Demchenko, I. (2016). Teoretychni i metodychni zasady pidhotovky maibutnoho vchytelia pochatkovykh klasiv do profesiinoi diialnosti v umovakh inkliuzyvnoi osvity [Theoretical and methodological foundations of training of the future teacher of elementary school for professional activity in the conditions of inclusive education (DSc thesis)]. Kyiv. [in Ukrainian].

5. Dubovyk, O. (2017). Osoblyvosti profesiino oriientovanykh osobystisnykh yakostei maibutnikh psykholohiv spetsialnykh zakladiv osvity [Peculiarities of professionally oriented personal qualities of future psychologists of special educational institutions]. Kyiv. [in Ukrainian].

6. Dyson, A. (1999). Inclusion and inclusions: Theories and discourses in inclusive education. Inclusive education. New York, NY: Routledge, 89-115.

7. Fedorenko, I. \& Fedorenko, M. (2017). Osoblyvosti formuvannia informatsiinoi kompetentnosti u maibutnikh spetsialnykh psykholohiv [Features of the formation of information competence of the future special psychologists]. 2, ch. I, p. 52-63.Osvitnii dyskurs: Humanitarni nauky - Educational Discourse: The humanities 2, 52-63. [in Ukrainian]

8. Florian, L., Linklater, H. (2010). Preparing teachers for inclusive education: using inclusive pedagogy to enhance teaching and learning for all Inclusive pedagogy in action: getting it right for every child. International Journal of Inclusive Education.

9. Forlin, C., Chambers, D., Loreman, T., Deppeler, J. \& Sharma, U. (2013). Inclusive education for students with disability: A review of the best evidence in relation to theory and practice. Report to the Australian Government Department of Education, Employment and Workplace Relations \& Australian Research Alliance for Children and Youth, Canberra.

10. Kanivets, T. (2015). Osoblyvosti formuvannia psykholohichnoi hotovnosti studentiv vyshchykh navchalnykh zakladiv do zdiisnennia maibutnoi profesiinoi kariery [Peculiarities of formation of psychological readiness of students of higher educational institutions to realization of the future professional career]. Orhanizatsiina psykholohiia. Ekonomichna psykholohiia - Organizational psychology. Economic Psychology, 1, 69-77. [in Ukrainian].

11. Kim, J.-R. (2011). Influence of teacher preparation programmes on preservice teachers' attitudes toward inclusion. International Journal of Inclusive Education, 15(3), 355-377.

12. Kolupaieva, A. A., Taranchenko, O. M. (2015). Pedahohichni tekhnolohii inkliuzyvnoho navchannia [Pedagogical technologies of inclusive education]. AA-Kyiv: ATOPOL. [in Ukrainian]

13. Leontev, A. N. (2005). Deiatelnost. Soznanye. Lychnost [Activity. Consciousness. Personality [2 nd ed.]. M.: Smysl; Akademyia. [in Russian]

14. Maksymenko, S. D. (1999) Do problemy rozrobky osvitno-kvalifikatsiinoi kharakterystyky suchasnoho psykholoha [On the problem of development of educational and qualification characteristics of the modern psychologist]. Praktychna psykholohiia ta sotsialna robota - Practical Psychology and Social Work , 2-6. [in Ukrainian] 
15. Panok, V. (2003). Osnovni napriamy profesiinoho stanovlennia osobystosti praktychnoho psykholoha u vyshchii shkoli [The main directions of professional development a practical psychologist's personality in high school]. Praktychna psykholohiia ta sotsialna robota, - Practical Psychology and Social Work 4, 14-16. [in Ukrainian]

16. Rudenko, L. \& Hryhorenko, T. (2019). Komponenty profesiinoi kompetentnosti psykholoha (spetsialnoho, klinichnoho) [Components of professional competence of psychologist (special, clinical)]. Aktualni pytannia korektsiinoi osvity (pedahohichni nauky) - Current issues of correctional education (pedagogycal sciences) 13, 219-232. [in Ukrainian]

17. Sheremet, M. \& Suprun, D.M. (2017). Self-realization in the context of psychologists' professional training in the field of special education. Materials of Ukrainian (correspondence) scientific and practical conference devoted to 5 th anniversary of the department correctional education and special psychology, 382-385.

18. Syniov V. M., Pometun O. I., Krivusha V. I., Suprun M. O. (1997). Osnovy teoriyi vihovannya [Basics of upbringing theory]. Kiev: MP Lesia [in Ukrainian].

19. Syniov, V. \& Suprun, D. (2016). Do pytannia profesiinoi pidhotovky psykholohiv $\mathrm{v}$ haluzi spetsialnoi osvity: yednist teoretychnoi i praktychnoi hotovnosti vyrishuvaty profesiini zavdannia. [On the issue of psychologists' professional training in the field of special education: the unity of the theoretical and practical readiness to solve professional tasks] Osvita ditei z osoblyvymy potrebamy: vid instytualizatsii do inkliuzii - Education of children with special needs: from institutionalization to inclusion. 319-320. [in Ukrainian].

20. Suprun, D. (2017). Profesiina pidgotovka psyhologiv v galuzi specialnoyi osvity (monographia) [Professional psychologists' training in the field of special education: a monograph]. Kyiv: Vyd-vo NPU imeni M.P. Dragomanova [in Ukrainian].

21. Suprun, D. (2018). Modernizatsiia zmistu profesiinoi pidhotovky psykholohiv v haluzi spetsialnoi osvity (monohrafiia) [Modernization of the content of psychologists' professional training in the field of special education: a monograph]. Kyiv: Vyd-vo NPU imeni M. P. Drahomanova [in Ukrainian].

22. Suprun, D. (2018). Teoriia ta praktyka profesiinoi pidhotovky psykholohiv $\mathrm{v}$ haluzi spetsialnoi osvity. (dys. ... d-ra ped. nauk: 13.00.03) [The theory and practice of psychologists' professional training in the field of special education. (DSc thesis)]. Kyiv [in Ukrainian].

23. Suprun, D. (2018). Management - a component of psychologists professional training (menedzhment - skladova profesiinoi pidhotovky psykholohiv). Kyiv.: Vyd-vo NPU imeni M. P. Drahomanova.

24. Suprun, M. (2005). Korektsiine navchannia uchniv dopomizhnih zakladiv osvity: vytoky, stanovlennia ta rozvytok (druga polovyna XIX-Persha polovyna of XX century.) [Correctional teaching of pupils in the special education institutions: preconditions, formation and development (second half of the XIX - first half of the of XX century)]. Kiev: View. KYUI MVSU Pal- ivoda AB [in Ukrainian].

\section{AUTHORS PROFILE}

\section{Viktor Syniov}

Dr. habil., Professor, Acting Member of the National Academy of Pedagogical Sciences of Ukraine, President of the Association of Special Pedagogues of Ukraine, National Pedagogical Dragomanov University, Ukraine

\section{Maria Sheremet}

Dr. habil., Professor, Honorary Academician of the National Academy of Pedagogical Sciences of Ukraine, Dean of the Faculty of Special and Inclusive Education Vice-President of the Association of Special Pedagogues of Ukraine, National Pedagogical Dragomanov University, 9, Pyrogova Str., Kyev, Ukraine,

\section{Daria Suprun}

Dr. habil., Professor of the department of Special Psychology and Medicine National Pedagogical Dragomanov University, , Ukraine

\section{Svitlana Fedorenko}

Dr. habil., Professor, head of the department of speech therapy and logopsychology, National Pedagogical Dragomanov University, Ukraine

\section{Myroslav Fedorenko}

$\mathrm{PhD}$ of pedagogy, associate professor of the department of Special Psychology and Medicine National Pedagogical Dragomanov University, Kyev, Ukraine

\section{Alla Dushka}

Doctor of psychological sciences, Associate professor, Chief Scientist of the Department of Psychological and Pedagogical Support of Children with Special Needs, Nichola Yarmachenko Institute of Special Pedagogics and Psychology of National Academy of Educational Sciences of Ukraine

\section{Vitalii Lunov*}

$\mathrm{PhD}$, Associate Professor, Bogomolets National Medical University, Ukraine, email: lunyov_vitaliy@ukr.net

\section{Olha Tsarkova}

Professor (Associate), Psy.D., Bogdan Khmelnitsky Melitopol state pedagogical university, Ukraine. 